"Factors determining co-operative small enterprises access to co-operative grant scheme in South Africa"

\begin{tabular}{ll} 
AUTHORS & $\begin{array}{l}\text { Timothy Olaniyi Aluko } \\
\text { Paul Kibuuka }\end{array}$ \\
\hline ARTICLE INFO & $\begin{array}{l}\text { Timothy Olaniyi Aluko and Paul Kibuuka (2016). Factors determining co- } \\
\text { operative small enterprises access to co-operative grant scheme in South Africa. } \\
\text { Public and Municipal Finance, 5(3), 22-31. doi:10.21511/pmf.5(3).2016.03 }\end{array}$ \\
\hline DOI & http://dx.doi.org/10.21511/pmf.5(3).2016.03 \\
\hline RELEASED ON & Monday, 12 December 2016 \\
\hline JOURNAL & "Public and Municipal Finance" \\
\hline FOUNDER & LLC "Consulting Publishing Company "Business Perspectives"
\end{tabular}

NUMBER OF REFERENCES

0

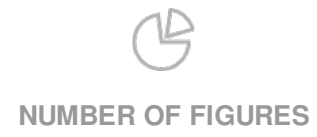

0

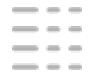

NUMBER OF TABLES

0

(C) The author(s) 2023. This publication is an open access article. 
Timothy Olaniyi Aluko (South Africa), Paul Kibuuka (South Africa)

\title{
Factors determining co-operative small enterprises access to co-operative grant scheme in South Africa
}

\begin{abstract}
This paper investigates factors determining co-operative small enterprises access to the co-operative grant incentive scheme in South Africa. The raw data used in this study were extracted from the Cooperative Incentive Scheme (CIS) database over the sample financial period FY 2010/11 to FY 2014/15. The amount approved was modelled as the dependent variable, while the turnover prior to application, number of employees, number of members, number of males, number of females, number of youth, number of the disabled, and purpose of application for additional capital were the exploratory variables in the model. Statistical Package for Social Sciences (SPSS) version 24 for Windows was used to perform data processing and statistical analysis using the multiple linear regression method for the overall model and stepwise multiple linear regression method at sectoral level. Estimated results indicate that turnover prior to application, the number of members, males, females and youth had a significant impact on the amount approved for the applications submitted by firms in the agricultural and manufacturing sectors during the sample financial years under review. The paper concludes that the department of small business development should focus on implementing strategies that promote access to the CIS grant funding targeting SMEs co-operatives in the agriculture and manufacturing sectors located mainly in the rural areas of South Africa.
\end{abstract}

Keywords: small and medium enterprises, co-operative, grant, incentive, South Africa. JEL Classification: L26, H81.

\section{Introduction}

Government support for small and medium enterprises (SMEs) appears to be based on the general notion that SME is an incubator of economic development. In South Africa, the issues of employment creation and poverty reduction put together have become a challenge to economic development, while demand for numbers of SMEs has increased over the last two decades (Chandler, 2012; Fatoki, 2012). This increase has been necessitated by individuals' desire to generate additional income through self-employment (Snow and Buss, 2001). Governments see this development as a way to fill the gap of high inequality in their societies (Fatoki, 2012). However, inadequate finance to support SMEs appears to be a challenge in terms of how or where to get funding and how government policies are structured in order to respond to the ongoing changes. In 2005, a Co-operatives Act (No 14 of 2005) was enacted, and in 2013 the Act was amended as Act No 6 of 2013. In South Africa, a co-operative is defined as "an autonomous association of natural persons united voluntarily to meet their common economic and social needs through a jointly owned and democratically controlled enterprise organized and operated under co-operative principle" (RSA, 2013).

\section{Co-operative Incentive Scheme ( $\mathrm{ClS}$ )}

This paper focuses on SMEs' access to Co-operative Incentive Scheme (CIS) that is aimed at improving the viability and competitiveness of co-operative

(c) Timothy Olaniyi Aluko, Paul Kibuuka, 2016.

Timothy Olaniyi Aluko, Ph.D. Candidate, University of Stellenbosch Business School, Cape Town, South Africa.

Paul Kibuuka, Associate Professor, University of South Africa, Pretoria, South Africa. enterprises in South Africa. The scheme was established in 2005 to provide $100 \%$ grant to the tune of R350 000 for registered primary co-operative enterprises (a primary co-operative consists of five or more members). The funding may be accessed in one application, or in a number of applications depending on what suits the individual co-operative enterprise (DTI, 2014). The scheme is funded by the National Treasury and administered by the Department of Small Business Development (DSBD) with focus on Broad-Based Black Economic Empowerment (B-BBEE) and historically disadvantaged communities. The scheme is to encourage cooperative enterprises to participate in the mainstream South African economy, generate income for their members and lower the cost of doing business.

\section{Problem statement}

SMEs have the capacity to not only reverse the phenomenon of rural-urban migration, but also nurture an indigenous enterprise culture. However, despite the enormous optimism regarding the role that small business can play in the employment generation and poverty reduction process, there are still some inherent problems that must be addressed in order to make the sector fulfil its objective of revolutionizing and increasing participation in the South African economy. Co-operative SMEs in South Africa, like their counterparts in other developing countries, have limited access to credit because of high transaction costs and lack of information (Ortmann and King, 2007). Moreover, SMEs are seen to be too risky, either because the entrepreneurs are too young or do not have sufficient credit history that could assist them to qualify for credit. 
Incentives schemes are carried out by giving out grants in the form of small loans or "microloans" to co-operative SMEs either to expand their existing businesses or to start new ones (Bradshaw, 2002; Glisovic and Martinez, 2012; Chandler, 2012). In South Africa, the role of grant incentive schemes is to support and promote black-owned SMEs that are presumed to be disadvantaged due to their business status of being too young, their lack of collateral and inability to cover high transaction costs.

The above provides a brief discussion of funding program for co-operative SMEs in South Africa. At the time of writing, no existing literature has been able to determine the status quo of the SMEs grant incentive schemes and their contributions to the South African economy.

\section{Research objective}

To investigate the factors determining access to cooperative grant incentive schemes for co-operative small enterprises in South Africa.

\section{Research question}

What are the factors determining access to cooperative grant incentive scheme for co-operative small enterprises in South Africa?

\section{Theoretical framework}

The theoretical framework for this study focuses on the joint liability financing approach. The joint liability financing approach refers to the practice of working with clients in small groups composed of four to five members. In this financing approach, funds are made to the group as a whole and members are held jointly liable in case there are repayment defaulters (Aghion and Morduch, 2000). This model serves as a risk pooling instrument even in the absence of collateral and complete information about financing access of a credit beneficiary (Ghatak, 1999).

1.1. Joint liability financing approach. According to Ghatak (1999), joint liability financing (also known as group-lending) is a financing program approach where borrowers who cannot offer any collateral are asked to form small groups where group members are held jointly liable for each other's debts; this induces borrowers to select their group members in a way that exploits local information. The lender focuses on the incentives induced by joint liability and this allows lenders to generate high repayment rates, even from clients who would usually be deemed too risky and that are too poor to offer collateral.

Joint liability financing has attracted female borrowers in Bangladesh, and has greatly improved their quality of life and the performance of lenders
(Ghatak, 1999). In the study conducted by Huppi and Freder (1990), joint liability financing was also studied, where loans made to self-selected groups of individuals with comparable economic status who belong to the same rural community were found to be more profitable than other loans. In addition, Impavido (1998) outlined that joint liability financing contributes to credit repayment plan and relaxes credit rationing, especially in an area where social ties are very strong.

From a randomized field experiment conducted in rural Mongolia, this model was recorded to be successful and to have positive impact on group entrepreneurship in terms of access to finance (Attanasio et al. 2011). Joint liability financing approach serves homogenous self-selected groups of individuals (Huppi and Freder, 1990). The use of sanctions from fellow group members helps to discipline members who misuse their capital; sanctions may involve, for example, the loss of an errant members' reputation in the community, social and economic isolation, and restrictions on access to further credit (Ghatak, 1999). In the theoretical analyses done by Wydick (2000), it was highlighted that peer monitoring andincentive for risk-taking are some of the potential benefits of group financing formation. It also fosters a reduction in competitive interest rates and serves as intra-group credit insurance due to the fact that members are not required to put in any collateral. Members from the same locality are expected to have some information about other members and their collective's projects because of depth of outreach compared to an individual borrower (Brau and Woller, 2004). Hence, the joint liability financing approach serves as a risk pooling strategy even in the absence of collateral and lack of full information about the beneficiaries and the potential cost of disappointment of one member motivate peers to monitor and discipline each other.

\section{Literature review}

It has been proven in some advanced countries such as the United States of America (USA), Canada, United Kingdom (UK), Australia and Japan that the growth of SMEs was commensurate with the level of resources used to develop them. Examples of these government intervention programs include: California State Loan Guarantee Program in the USA (Bradshaw, 2002); Canada Small Business Financing Program (CSBFP) (Chandler, 2012); Working Capital and Enterprise Finance Scheme in UK (Richard 2008), Early Stage Venture Capital Limited Partnerships (ESVCLP) and Textile, Clothing and Footwear (TCF) Small Business Program in Australia (Xiang and Worthington, 2013). All of these programs are constantly being evaluated, leading to several reforms and policies around what 
incentive schemes may be best suited for SMEs in order to achieve positive impact on economies of developing countries.

In the last two decades, co-operative enterprises have played an important role in the development of South Africa's economy; particularly in the agricultural sector (Van der Walt's, 2005; Ortmann and King, 2007). The South African government used this avenue to promote co-operatives as organizations that could help to enhance the development of small-scale farmers in the rural areas and encourage them to participate in the mainstream South African economy. Kallon (1990) and Kiggundu (2002) both opined that one of the long lasting, major obstacle confronting co-operative enterprise in the developing countries is essentially the issue of financial resources, that is, the availability of capital to start or to expand a business venture. In South Africa, government support for co-operative enterprises has improved in the last two decades with majority of them operating in the agricultural sector (Ortmann and King, 2007).

Notwithstanding, according to Van der Walt (2005), co-operative enterprises still have a high failure rate in South Africa. The study shows that $65 \%$ of the survey respondents were not operating and close to $60 \%$ experienced a decrease in their turnover. Moreover, the study also found that lack of access to credit, poor management, conflict and lack of skill among cooperative members are the major reasons responsible for high failure rate of co-operative enterprises. However, in a study conducted in Osun State of Nigeria by Adekunle and Henson (2007), it was discovered that micro-entrepreneurs who belong to a joint liability group such as the "Co-operative Thrift and Credit Societies" have better personal agency approach in terms of access to financing than those micro-entrepreneurs who are not members.

It can be seen from various literature reviewed that the group financing model is efficient, but also has its shortcomings. For example, joint liability creates tensions within a group and can lead to voluntary withdrawal of a member as a result of the member's damaged social capital (Giné and Karlan, 2009). Also, members that ride on the back of others increase the failure rates of groups, as the repayment is sometimes too much for safer members leading to higher rates of default. Moreover, the study conducted by Mknelly and Kevane (2002) observed a credit program designed for women in Burkina Faso which showed negative results on the impact of joint liability approach. This was because of the high expectation in the mutual trust among enterprise members and collective beliefs among credit institutions. The study though concluded that program implementation needs to be more consistent, follow proper procedures of recovering debts and mitigate against allocating funds to non-performing members.

\section{Methodology and estimation technique}

3.1. Data. The raw data used in this study were extracted from the Co-operative Incentive Scheme (CIS) database over the sample financial period FY 2010/11 to FY 2014/15. Data preparation and processing were performed using appropriate methods. The variables for which data were collected include sector of the firm, purpose for application, approved amount, turnover prior to application, number of employees, numbers of males, females, youth, and the disabled members.

3.2. Statistical analysis. The Statistical Package for Social Sciences (SPSS) version 24 for Windows was used to perform statistical analysis. Frequencies, descriptive statistics, multiple and stepwise multiple linear regressions were conducted in the analysis.

3.3. Descriptive statistics. Descriptive statistics which include minimum, maximum, sum, mean, standard and deviation were computed. This was done for the purpose of determining the application and approved amount, turnover prior to application, number of employees (see Appendix 1), in addition to the number of members (see Appendix 2), males, females, youth, and disabled.

3.4. Multiple and stepwise linear regressions. The multiple linear regression through the origin for the overall model, and stepwise multiple linear regression through the origin at sectoral level were performed to determine the impacts distinct exploratory variables had on the amount approved. The exploratory variables analyzed include purpose for application, turnover prior to application, numbers of employees, males, females, youth, and disabled members. The stepwise multiple regression approach was applied to determine exploratory variables that had statistically significant impacts on access to additional capital for which "approved amount" was the proxy for access to additional capital. The statistical estimation model was specified as:

$$
\begin{aligned}
& A p p r_{-} A m t_{i t}=\widetilde{\beta}_{1}\left(T A_{i t}\right)+\widetilde{\beta}_{2}\left(N E_{i t}\right)+\widetilde{\beta}_{3}\left(N M_{i t}\right)+ \\
& +\widetilde{\beta}_{4}\left(\vartheta_{i t}\right)+\widetilde{\beta}_{5}\left(\chi_{i t}\right)+\varepsilon_{i t},
\end{aligned}
$$

where: Appr_Amt represents the approved amount, $T A$ denotes the turnover amount prior to application, $N E$ represents number of employees, $N M$ symbolizes number of members, $\vartheta$ represents a $1 \times 2$ vector of gender (male and female) and $\chi$ is a $1 \times 3$ vector of variables which include number of youth, number of the disabled, and purpose for application of additional capital. While the Appr_Amt was modelled as 
the dependent variable, turnover amount prior to application, number of employees, number of members, number of males, number of females, number of youth, number of the disabled, and purpose for application of additional capital were the exploratory variables in the model. The $\beta$ s represent the estimated coefficients at $95 \%$ confidence interval, while $\varepsilon$ represents the error term of the estimated models. The respective econometric model was further applied at sectoral level to determine the impact of each of the covariates on approved amount for additional capital in each distinct sector. The specific sectors that were analyzed at individual level are the agricultural sector and the manufacturing sector.

\section{Results and analysis}

This section provides results on descriptive statistics and multiple linear regression for overall model and stepwise multiple linear regression at sectoral level analysis performed.

4.1. Descriptive statistics. Results on descriptive statistics presented in this section include the minimum and maximum values, sums, arithmetic means and standard deviations on the purpose for application, approved amount, turnover prior to application, number of employees, males, females, youth, and disabled for the entire dataset across all two (agricultural sector and manufacturing sector) sectors and at individual sectoral level.

Table 1. Descriptive statistics across both sectors

\begin{tabular}{|l|c|c|c|c|c|c|}
\hline \multicolumn{1}{|c|}{ Variable } & N & Minimum & Maximum & Sum & Mean & $\begin{array}{c}\text { Standard } \\
\text { Deviation } \\
74636.763\end{array}$ \\
\cline { 1 - 6 } Approved amount & 386 & 12297 & 351806 & 106614890 & 276204.38 & 333176.839 \\
\hline Turnover prior to application & 386 & 0 & 3436125 & 179334202 & 464596.38 & 20.824 \\
\hline Number of employees & 386 & 0 & 352 & 3876 & 10.04 & 5.335 \\
\hline Number of members & 386 & 0 & 50 & 3384 & 3.77 & 3.124 \\
\hline Male & 386 & 0 & 26 & 1283 & 3.32 & 4.293 \\
\hline Female & 386 & 0 & 35 & 1650 & 4.27 & 2.366 \\
\hline Youth & 386 & 0 & 30 & 499 & 1.30 & .241 \\
\hline Disabled & 386 & 0 & 3 & 15 & 64 & .442 \\
\hline Purpose & 386 & 1 & 2 & 670 & 1.74 & .850 \\
\hline Sector & 386 & 1 & 3 & 568 & 1.47 & \\
\hline
\end{tabular}

Based on the minimum and maximum statistics in Table 1, the least amount of turnover prior to application was R12 297, while the highest amount was R351 806. During the financial period FY 2010/11 to 2014/15, a total of R106 614890 was approved for all the 386 firms across agricultural and manufacturing sectors. In respect of the turnover prior to application, the firm with the least turnover had R0.00. This meant that firms are not mandated to be operating as long they meet the requirements of being co-operative enterprises. The firm with the highest amount had R3 436125 , while cumulatively all firms had a total amount of R179 334202 turnover prior to application.
The mean turnover prior to application for the firms amounted to R464 596.38 with a standard deviation of R333 176.84 during the period under review. The largest numbers for each of the demographic variables were 352 employees, 50 members, 26 males, 35 females, 30 youth and 3 disabled. The standard deviations show that there were significant variations in approved amount ( $\mathrm{SD}=\mathrm{R} 74636.763)$, turnover prior to application ( $\mathrm{SD}=\mathrm{R} 333$ 176.84), and number of employees $(\mathrm{SD}=21)$. Conversely, there were insignificant variations in number of members $(\mathrm{SD}=5)$, males $(\mathrm{SD}=3)$, females $(\mathrm{SD}=4)$, youth $(\mathrm{SD}=2)$, and the disabled $(\mathrm{SD}=0)$.

Table 2. Descriptive statistics at sectoral level

\begin{tabular}{|c|c|c|c|c|}
\hline Sector & Variable & Mean & Std. Deviation & $\mathrm{N}$ \\
\hline \multirow{8}{*}{ Agriculture } & Approved amount & 289331.65 & 64219.426 & \multirow{8}{*}{294} \\
\hline & Turnover prior to application & 449101.93 & 292962.834 & \\
\hline & Number of employment & 10.23 & 23.491 & \\
\hline & Number of members & 8.60 & 4.204 & \\
\hline & Male & 3.74 & 3.025 & \\
\hline & Female & 3.64 & 2.799 & \\
\hline & Youth & 1.28 & 2.447 & \\
\hline & Disabled & 0.03 & 0.217 & \\
\hline \multirow{4}{*}{ Manufacturing } & Approved amount & 233259.49 & 89161.344 & \multirow{4}{*}{92} \\
\hline & Turnover prior to application & 519760.84 & 434957.060 & \\
\hline & Number of employment & 9.47 & 7.608 & \\
\hline & Number of members & 9.34 & 7.981 & \\
\hline
\end{tabular}


Table 2 (cont.). Descriptive statistics at sectoral level

\begin{tabular}{|l|l|c|c|c|}
\multicolumn{1}{|c|}{ Sector } & \multicolumn{1}{c|}{ Variable } & Mean & Std. Deviation & $\mathrm{N}$ \\
\hline \multirow{3}{*}{ Manufacturing } & Male & 1.98 & 3.088 & \\
& Female & 6.32 & 6.914 & 92 \\
& Youth & 1.36 & 2.095 & \\
& Disabled & 0.08 & 0.307 & \\
\hline
\end{tabular}

As shown in Table 2, the agricultural sector had the highest average approved of capital amounting to R289 331.65 relative to the average approved amount of R233 259.49 in the manufacturing sector during the financial year periods FY 2010/11 to FY $2014 / 15$. On the contrary, the largest average turnover prior to application was R519760.84 in the manufacturing sector relative to an average turnover prior to application amounting to R449 101.93 in the agricultural sector. There were significant differences in the average numbers of employment, number of members, males, females, youths and the disabled between the agricultural and manufacturing sectors.

\subsection{Multiple linear regression.}

\subsubsection{Both (agriculture and manufacturing) sectors.}

Table 3. Model summary ${ }^{\mathrm{c}, \mathrm{d}}$

\begin{tabular}{|c|c|c|c|c|c|}
\hline Model & $\mathrm{R}$ & R Square $^{\mathrm{b}}$ & Adjusted R Square & Std. Error of the Estimate & Durbin-Watson \\
\hline 1 & $.900^{\mathrm{a}}$ & .810 & .807 & 125520.206 & 1.658 \\
\hline a. Predictors: Youth, Male, Female, Turnover prior to application, Number of members \\
\hline
\end{tabular}

Based on model summary estimates (Table 3 ), the adjusted R-Square results, about $80.7 \%$ overall variation in approved amount in both (agricultural and manufacturing) sectors was accounted for by number of members, turnover prior to application, males and youth. Therefore, the results reveal that number of members, turnover prior to application, males, females and youth had significance in approval of additional capital applied by firms in the agricultural and manufacturing sectors during the sample period under review.

Table 4. Coefficients ${ }^{\mathrm{a}, \mathrm{b}}$

\begin{tabular}{|c|c|c|c|c|c|c|c|c|}
\hline \multirow{2}{*}{\multicolumn{2}{|c|}{ Model }} & \multicolumn{2}{|c|}{ Unstandardized coefficients } & \multirow{3}{*}{$\begin{array}{c}\begin{array}{c}\text { Standardized } \\
\text { coefficients } \\
\text { Beta }\end{array} \\
.417 \\
\end{array}$} & \multirow{3}{*}{$\begin{array}{c}t \\
13.734 \\
\end{array}$} & \multirow{3}{*}{$\begin{array}{l}\text { Sig. } \\
.000\end{array}$} & \multicolumn{2}{|c|}{$95.0 \%$ confidence interval for $B$} \\
\hline & & \multirow{2}{*}{$\begin{array}{c}\mathrm{B} \\
.208 \\
\end{array}$} & \multirow{2}{*}{$\begin{array}{c}\text { Std. Error } \\
.015\end{array}$} & & & & & \\
\hline \multirow{5}{*}{1} & Turnover prior to application & & & & & & .178 & .238 \\
\hline & Number of members & 7497.902 & 3000.392 & .269 & 2.499 & .013 & 1598.451 & 13397.353 \\
\hline & Male & 14460.758 & 3666.415 & .231 & 3.944 & .000 & 7251.755 & 21669.761 \\
\hline & Female & 3238.671 & 3013.859 & .069 & 1.075 & .283 & -2687.258 & 9164.600 \\
\hline & Youth & 8326.195 & 3303.478 & .078 & 2.520 & .012 & 1830.809 & 14821.581 \\
\hline
\end{tabular}

Model coefficients results in Table 4 indicate that turnover prior to application, number of members, males and youth all demonstrated statistically significant and positive effects on the amounts approved for firms in agricultural and manufacturing sectors during the financial years period FY $2010 / 10$ to FY 2014/15. The $t$-statistics reveal that turnover prior to application $(\mathrm{t}=13.734)$ had the highest significant and positive effect on the amount approved; followed by males $(\mathrm{t}=3.944)$, youth $(\mathrm{t}=2.520)$, while number of members had the least $(\mathrm{t}=2.499)$ statistically significant and positive effect on amount approved. Nonetheless, although the female variable had a positive effect on amount approved, but the effect was statistically insignificant $(\mathrm{t}=1.075 ; \mathrm{p}>0.05)$ at $5 \%$ significance level.

Based on estimated coefficients, for every $1 \%$ increase in the amount of turnover prior to application, approximately $0.42 \%$ of additional capital was approved. Correspondingly, for every $1 \%$ increase in number of members, about $0.37 \%$ of the total amount applied for was approved. Furthermore, a $1 \%$ increase in the males resulted in about $0.18 \%$ increase in the total amount approved, while for every $1 \%$ increase in youth, there was a corresponding increase of about $0.06 \%$ in the total amount approved during the sample period 2010/11 to $2014 / 15$. 
4.2.2. Sector level analysis. The stepwise multiple linear regression through the origin was performed for sectors with firms the sample sizes of which were considered large for inferential purposes based on sample size determination statistical principles and practices. Based on the standard statistical prin- ciples, a sample size less than 30 is considered small. In this study, only the agricultural sector ( $\mathrm{n}=$ 294) and manufacturing sector $(n=92)$ had large sample sizes; hence, the agricultural and manufacturing sectors were the only two sectors considered and used in this study.

\subsubsection{Agricultural sector.}

Table 5. Model summary ${ }^{\mathrm{d}, \mathrm{e}, \mathrm{f}}$

\begin{tabular}{|c|c|c|c|c|c|c|c|}
\hline \multirow[b]{2}{*}{ Model } & \multicolumn{2}{|r|}{$\mathrm{R}$} & \multirow[b]{2}{*}{ R-Square ${ }^{b}$} & \multirow{2}{*}{$\begin{array}{l}\text { Adjusted R- } \\
\text { Square }\end{array}$} & \multirow{2}{*}{$\begin{array}{l}\text { Std. Error of the } \\
\text { estimate }\end{array}$} & \multicolumn{2}{|c|}{ Durbin-Watson Statistic } \\
\hline & $\begin{array}{l}\text { Sector = Agricul- } \\
\text { ture (selected) }\end{array}$ & $\begin{array}{l}\text { Sector } \sim=\text { Agriculture } \\
\text { (unselected) }\end{array}$ & & & & $\begin{array}{l}\text { Sector = Agricul- } \\
\text { ture (selected) }\end{array}$ & $\begin{array}{l}\text { Sector } \sim=\text { Agricul- } \\
\text { ture (unselected) }\end{array}$ \\
\hline 1 & $.887 \mathrm{a}$ & & .786 & .785 & 137334.307 & & \\
\hline 2 & $.929 c$ & 1.000 & .862 & .861 & 110390.501 & 1.515 & 1.799 \\
\hline \multicolumn{8}{|c|}{ d. Unless noted otherwise, statistics are based only on cases for which Sector = Agriculture. } \\
\hline \multicolumn{8}{|c|}{ e. Dependent Variable: Approved amount } \\
\hline \multicolumn{8}{|c|}{ f. Linear regression through the origin } \\
\hline
\end{tabular}

Model 2 adjusted R-Square results in Table 5 show that approximately $86.1 \%$ overall variation in approved amount in the agricultural sector was accounted for by number of members and turnover prior to application. The Durbin-Watson statistic (DW statistic $=1.799)$ statistically reveals absence of autocorrelation in the estimated model.

Table 6. Coefficients ${ }^{\mathrm{a}, \mathrm{b}, \mathrm{c}}$

\begin{tabular}{|c|c|c|c|c|c|c|c|c|}
\hline \multirow{2}{*}{\multicolumn{2}{|c|}{ Model }} & \multicolumn{2}{|c|}{ Unstandardized coefficients } & \multirow{3}{*}{$\begin{array}{c}\text { Standardized coeffi- } \\
\text { cients } \\
\text { Beta } \\
.887\end{array}$} & \multirow{2}{*}{$\mathrm{t}$} & \multirow{2}{*}{ Sig. } & \multicolumn{2}{|c|}{$95.0 \%$ confidence interval for B } \\
\hline & & B & Std. Error & & & & Lower bound & Upper bound \\
\hline 1 & Number of members & 27458.440 & 837.093 & & 32.802 & .000 & 25810.962 & 29105.917 \\
\hline \multirow[t]{2}{*}{2} & Number of members & 18473.342 & 976.054 & .596 & 18.927 & .000 & 16552.350 & 20394.335 \\
\hline & $\begin{array}{l}\text { Turnover prior to } \\
\text { application }\end{array}$ & .221 & .017 & .400 & 12.708 & .000 & .187 & .256 \\
\hline \multicolumn{9}{|c|}{ a. Dependent variable: approved amount } \\
\hline \multicolumn{9}{|c|}{ b. Linear regression through the origin } \\
\hline \multicolumn{9}{|c|}{ c. Selecting only cases for which Sector $=$ Agriculture } \\
\hline
\end{tabular}

The t-statistics in Table 6 indicate that the number of members $(t=18.927)$ had the highest statistically significant and positive effect on the amount approve; followed by $(\mathrm{t}=12.708)$ turnover prior to application. The corresponding estimated coefficients show that for every $1 \%$ increase in the number of members, there was a corresponding increase of about $0.60 \%$ in amount approved. Similarly, for every $1 \%$ rise in turnover prior to application, there was a rise of about $0.40 \%$ in the total amount approved.

\subsubsection{Manufacturing sector.}

Table 7. Model summary ${ }^{\mathrm{e}, \mathrm{f}, \mathrm{g}}$

\begin{tabular}{|c|c|c|c|c|c|c|c|}
\hline \multirow[b]{2}{*}{ Model } & \multicolumn{2}{|c|}{$\mathrm{R}$} & \multirow[b]{2}{*}{ R-Squareb } & \multirow{2}{*}{$\begin{array}{l}\text { Adjusted R- } \\
\text { Square }\end{array}$} & \multirow{2}{*}{$\begin{array}{l}\text { Std. Error of } \\
\text { estimate }\end{array}$} & \multicolumn{2}{|c|}{ Durbin-Watson Statistic } \\
\hline & $\begin{array}{l}\text { Sector = Manufac- } \\
\text { turing (selected) }\end{array}$ & $\begin{array}{l}\text { Sector } \sim=\text { Manufac- } \\
\text { turing (unselected) }\end{array}$ & & & & $\begin{array}{l}\text { Sector = Manufactur- } \\
\text { ing (selected) }\end{array}$ & $\begin{array}{l}\text { Sector } \sim=\text { Manufac- } \\
\text { turing (unselected) }\end{array}$ \\
\hline 1 & $.751^{\mathrm{a}}$ & & .563 & .559 & 165791.60 & \multirow{3}{*}{1.596} & \multirow{3}{*}{1.417} \\
\hline 2 & $.826 \mathrm{c}$ & & .683 & .676 & 142098.20 & & \\
\hline 3 & $.841^{\mathrm{d}}$ & 1.000 & .707 & .697 & 137376.21 & & \\
\hline \multicolumn{8}{|c|}{ e. Unless noted otherwise, statistics are based only on cases for which Sector = Manufacturing. } \\
\hline \multicolumn{8}{|c|}{ f. Dependent variable: approved amount } \\
\hline
\end{tabular}

Based on model 3 is the final iteration, the adjusted R-Square results in table 7 show that approximately $70.7 \%$ overall variation in approved amount in the manufacturing sector was ac- counted for by the number of employees and turnover prior to application. The Durbin Watson statistic $(\mathrm{DW}=1.417)$ reveals absence of autocorrelation in the model. 
Table 8. Coefficients ${ }^{\mathrm{a}, \mathrm{b}, \mathrm{c}}$

\begin{tabular}{|c|c|c|c|c|c|c|c|c|}
\hline \multirow{2}{*}{\multicolumn{2}{|c|}{ Model }} & \multicolumn{2}{|c|}{ Unstandardized coefficients } & \multirow{3}{*}{$\begin{array}{c}\text { Standardized } \\
\text { coefficients }\end{array}$} & \multirow{3}{*}{$\begin{array}{c}t \\
10.778\end{array}$} & \multirow{3}{*}{$\begin{array}{l}\text { Sig. } \\
.000\end{array}$} & \multicolumn{2}{|c|}{$95.0 \%$ confidence interval for B } \\
\hline & & \multirow{2}{*}{$\begin{array}{c}\text { B } \\
15451.360 \\
\end{array}$} & \multirow{2}{*}{$\begin{array}{l}\text { Std. Error } \\
1433.613\end{array}$} & & & & & \\
\hline 1 & Number of employees & & & & & & 12603.238 & 18299.482 \\
\hline \multirow[t]{2}{*}{2} & Number of employees & 10322.632 & 1514.800 & .501 & 6.815 & .000 & 7312.757 & 13332.507 \\
\hline & $\begin{array}{l}\text { Turnover prior to applica- } \\
\text { tion }\end{array}$ & .157 & .027 & .426 & 5.789 & .000 & .103 & .211 \\
\hline \multirow[t]{3}{*}{3} & Number of employees & 8638.051 & 1592.956 & .420 & 5.423 & .000 & 5472.386 & 11803.716 \\
\hline & $\begin{array}{l}\text { Turnover prior to applica- } \\
\text { tion }\end{array}$ & .144 & .027 & .391 & 5.413 & .000 & .091 & .197 \\
\hline & Youth & 18824.194 & 7003.946 & .188 & 2.688 & .009 & 4905.324 & 32743.065 \\
\hline \multicolumn{9}{|c|}{ a. Dependent variable: approved amount } \\
\hline \multicolumn{9}{|c|}{ b. Linear regression through the origin } \\
\hline \multicolumn{9}{|c|}{ c. Selecting only cases for which Sector = Manufacturing } \\
\hline
\end{tabular}

Based on model 3 (Table 8) t-statistics, the number of employees $(\mathrm{t}=5.423)$ had the relatively highest significant and positive effect on the amount approved; followed by the turnover prior to application $(\mathrm{t}=5.413)$, and youth $(\mathrm{t}=2.688)$. The coefficients show that for every $1 \%$ increase in the number of employees, there was a corresponding increase of about $0.42 \%$ in amount approved, and for every $1 \%$ rise in turnover prior to application, there was an increase of about $0.391 \%$ in the amount approved. Lastly, for every $1 \%$ rise in the youth, there was an increase of approximately $0.19 \%$ in the approved amount during the sample period FY 2010/11 to $2014 / 15$.

\section{Conclusion}

This paper focuses on factors that determine cooperative small enterprises access to co-operative incentive scheme funding in South Africa. CIS is intended to provide incentive grant to co-operative small enterprises that are registered as co-operative enterprises with a minimum of four members and operate principally in the rural areas of South Africa. CIS is targeted at assisting enterprises to cover their operational cost and also to participate actively in the mainstream South African economy. These co-operative small enterprises may be pre-existing or newly registered co-operative enterprises under the South African Co-operatives Act of 2013. The outcome of our multiple linear regression analysis results shows that turnover prior to application had the highest significant and positive effect on the amount approved followed by the numbers of members. However, at sectoral level analysis, the outcome of our stepwise multiple regression approach results showed that the numbers of members had the highest statistically significant and positive effect on the amount approved, compared to turnover prior to application. Although, our t-statistics results also revealed that turnover prior to application $(t=13.799)$ had the highest significant and positive effect on the amount approved, followed by number of members $(\mathrm{t}=7.737)$, male $(\mathrm{t}=4.743)$, while youth (2.284) had the least significant and positive effect during the sample period 2010/11 to 2014/15.

The results corroborated with the earlier study by Adekunle and Henson (2007) that microentrepreneurs who are members of Co-operative Thrift and Credit Societies have better personal agency approach in terms of access to financing compared to those micro-entrepreneurs that are not. Also, Brau and Woller (2004) confirmed in their study that members of a group were highly favored in terms of access to financing than individuals, due to the fact that members are not required to put in any collateral when applying for finance (Wydick, 2000; Attanasio et al., 2011).

However, our descriptive results show that the least amount of turnover prior to application was R12 297, while R351 806 was the highest amount indicated. The corresponding estimated coefficients show that for every $1 \%$ increase in the number of members, there was a corresponding increase of about $0.60 \%$ in the amount approved. Similarly, for every $1 \%$ rise in turnover prior to application, there was a rise of about $0.40 \%$ in the total amount approved. Moreover, for every $1 \%$ increase in the number of members, about $0.37 \%$ of the total amount applied for was approved. Based on estimated coefficients, the results indicate that for every $1 \%$ increase in the amount turnover prior to application, approximately $0.42 \%$ of additional capital was approved and for every $1 \%$ increase in the number of members, about $0.37 \%$ of total amount applied for also approved.

Out of the total sample for the period under study, the agricultural sector had the largest sample size $(n=294)$ of the two sectors studied (agricultural and manufacturing sectors). Our results showed that approximately $86.1 \%$ overall variation in approved amount in the agricultural sector was accounted for by number of members and turnover prior to application. In the manufacturing sector which accounted 
for $\mathrm{n}=92$, approximately $70.7 \%$ accounted for by the number of employees and turnover prior to application in overall variation of the approved amount. From our model summary estimated for both agricultural and manufacturing sectors, the adjusted R-Square results show about $80.7 \%$ overall variation in the approved amount. This was accounted for by the number of members, turnover prior to application, males and youths. Therefore, our results reveal that the number of members, turnover prior to application, males, females and youths had significance in approval of capital for firms in both agricultural and manufacturing sectors during the sample period under review.

Moreover, our t-statistics have shown that the number of employees $(t=5.423)$ had the relatively highest significant and positive effect on the amount approved; followed by the turnover prior to application $(\mathrm{t}=5.413)$, and youth $(\mathrm{t}=2.688)$. This is also corroborated by coefficients results which have shown that for every $1 \%$ increase in number of employees, there was a corresponding increase of about $0.42 \%$ in the amount approved, and for every $1 \%$ rise in turnover prior to application, there was an increase of about $0.391 \%$ in the amount approved. Lastly, for every $1 \%$ rise in the youth, there was an increase of approximately $0.19 \%$ in the approved amount during the sample period FY 2010/11 to 2014/15.

\section{Recommendations}

The outcome of our results provides useful guidelines for individual entrepreneurs intending to form a small co-operative enterprise with a view to access CIS grant or participating in other funded programs in South Africa. The study could also assist government, non-governmental organizations (NGOs) and other development finance institutions in designing and developing an efficient product value chain for the agriculture and manufacturing cooperative sector in order to provide potential benefits and support under governmentfunding programs. The outcome of our estimation results in this study also provides an indication that co-operative enterprises operate more in the agriculture and manufacturing sectors. Literature also confirms that these two sectors play an important role in the economic development of any nation in terms of food security and employment creation. Therefore, it is important for the South African government to place more emphasis on these two sectors in its effort towards the effective reform of co-operative enterprise, and publicity of the CIS incentive grant programs. Lastly, the Department of Small Business Development should focus on implementing strategies that promote access to CIS grant funding that targets SME co-operatives, most importantly those in the rural areas of South Africa.

\section{References}

1. Adekunle, B. and Henson, S.J. (2007). The effect of cooperative thrift and credit societies on personal agency belief: a study of entrepreneurs in Osun State, Nigeria, African Journal of Agricultural Research, 2 (12), pp. 678686, December 2007.

2. Aghion, B.A. and Morduch, J. (2000). Microfinance Beyond Group Lending; University College London April 25, 2000. [Online]. Available at: www.nyu.edu/projects.

3. Al-Azzam, M. and Mimouni, K. (2012). What types of Social ties improve Repayment in Group Lending? International research Journal of Finance and Economics, 87, pp. 25-32.

4. Attanasio, A., Augsburg, B., De Haas, R., Fitzsimons, E. and Harmgart, H. (2011). Group lending or individual lending? Evidence from a randomised field experiment in Mongolia. European Bank for Reconstruction and Development, December 2011. [Online] Available at: http://mpra.ub.uni-muenchen.de/35439/ MPRA Paper No. 35439, posted 16.

5. Bradshaw, T. (2002). The Contribution of Small Business Loan Guarantees to Economic Development. Economic Development Quarterly, 16 (4), pp. 360-369.

6. Brau, J.C. and Woller, G.M. (2004). Microfinance: A Comprehensive Review of the Existing Literature, Journal of Entrepreneurial Finance and Business Ventures, 9 (1), pp. 1-26.

7. Bruno, C., Florencia, D., Esther, D. and William, P. (2011). Impact of microcredit in rural areas of Morocco: Evidence from a Randomized Evaluation. March 31, 2011 Working Paper.

8. Chandler, V. (2012). The economic impact of the Canada small business financing program, Small Business Economics, 39 (1), pp. 253-264.

9. Chowdhury, P.R. (2005). Group-lending: Sequential financing, lender monitoring and joint liability. Journal of Development Economics, 77, pp. 415-439.

10. Department Trade and Industry (DTI). (2014). Available at: http://www.dti.gov.za/financial_assistance/financial_incentives.jsp [accessed 10 July 14].

11. Fatoki, O. (2012). Entrepreneurial Orientation, Debt Finance and Performance of Small and Medium Enterprises in South Africa, Journal of Social Science, 32 (2), pp.121-131.

12. Ghatak, M. (1999). Group lending, local information and peer selection, Journal of Development Economics, 60 (1), pp. $27-50$.

13. Giné, X. and Karlan, D. (2009). Group versus individual liability: long term evidence from Philippine microcredit lending groups. The World Bank, Yale University, Innovations for Poverty Action, Jameel Poverty Action Lab, and Financial Access Initiative. 
14. Glisovic, J., and Martinez, M. (2012). Financing Small Enterprises: What Role for Microfinance Institutions? Focus Note 81. Washington, D.C.: CGAP, July, 2012.

15. Huppi, M. and Feder, H.G. (1990). The Role of Groups and Credit Cooperatives In Rural Lending, The World Bank Research Observer, 5 (2), Jul. 1990, pp. 187-204. Published by Oxford University Press.

16. Kallon, K.M. (1990). The economics of Sierra Leonean entrepreneurship (pp. 41-55). Lanhan, MD: University Press of America.

17. Khandker, S.R. (2005). Microfinance and Poverty: Evidence Using Panel Data from Bangladesh. The World Bank Economic Review Advance Access published September 8, 2005.

18. Kiggundu, M.N. (2002). Entrepreneurs and entrepreneurship in Africa: What is known and what needs to be done, Journal of Developmental Entrepreneurship, 7 (3), pp. 239-258.

19. Mknelly, B. and Kevane, M. (2002). Improving Design and Performance of Group Lending: Suggestions from Burkina Faso, World Development, 30, (11), pp. 2017-2032, Elsevier Science Ltd.

20. Ortmann, G.F. \& King, R.P. (2007). Agricultural cooperatives II: Can they facilitate access of small-scale farmers in South Africa to input and product markets? Agrekon, 46 (2), pp. 219-244. DOI: 10.1080/03031853.2007.9523769.

21. Richard. (2008). Small Business and Government: [Online] Available at: http://www.bl.uk/bipc/pdfs/richardreport2008.pdf [accessed 16 July 14].

22. RSA (Republic of South Africa). (2013). Co-operatives Act, 2005. Government Gazette, 05 August 2013, Cape Town, South Africa.

23. Snow, D.R. and Buss, T.F. (2001). Development and the Role of Microcredit, Policy studies Journal, 29 (2):pp. 296-307.

24. Van der Walt, L. (2005). The resuscitation of the cooperative sector in South Africa. Paper presented at the International Co-operative Alliance XXI International Cooperative Research Conference, Cork, Ireland.

25. Wydick, B. (2001). Group lending under dynamic incentives as a borrower discipline device, Review of Development Economics, 5 (3), pp. 406-20.

26. Xiang, D. \& Worthington, A.C. (2013). The impact of government financial assistance on SMEs in Australia during the GFC (No. finance: 201307). [Accessed 16 July 14].

Appendix 1. Number of employees

\begin{tabular}{|c|c|c|c|c|}
\hline Valid & Frequency & Percent & Valid Percent & Cumulative Percent \\
\hline 0 & 9 & 2.3 & 2.3 & 2.3 \\
\hline 4 & 2 & .5 & .5 & 2.8 \\
\hline 5 & 131 & 33.9 & 33.9 & 36.8 \\
\hline 6 & 21 & 5.4 & 5.4 & 42.2 \\
\hline 7 & 35 & 9.1 & 9.1 & 51.3 \\
\hline 8 & 40 & 10.4 & 10.4 & 61.7 \\
\hline 9 & 34 & 8.8 & 8.8 & 70.5 \\
\hline 10 & 26 & 6.7 & 6.7 & 77.2 \\
\hline 11 & 20 & 5.2 & 5.2 & 82.4 \\
\hline 12 & 20 & 5.2 & 5.2 & 87.6 \\
\hline 13 & 7 & 1.8 & 1.8 & 89.4 \\
\hline 14 & 7 & 1.8 & 1.8 & 91.2 \\
\hline 15 & 2 & .5 & .5 & 91.7 \\
\hline 16 & 9 & 2.3 & 2.3 & 94.0 \\
\hline 17 & 2 & .5 & .5 & 94.6 \\
\hline 18 & 1 & .3 & .3 & 94.8 \\
\hline 19 & 1 & .3 & .3 & 95.1 \\
\hline 20 & 3 & .8 & .8 & 95.9 \\
\hline 21 & 1 & .3 & .3 & 96.1 \\
\hline 24 & 2 & .5 & .5 & 96.6 \\
\hline 26 & 2 & .5 & .5 & 97.2 \\
\hline 30 & 2 & .5 & .5 & 97.7 \\
\hline 35 & 4 & 1.0 & 1.0 & 98.7 \\
\hline 41 & 1 & .3 & .3 & 99.0 \\
\hline 43 & 1 & .3 & .3 & 99.2 \\
\hline 45 & 1 & .3 & .3 & 99.5 \\
\hline 200 & 1 & .3 & .3 & 99.7 \\
\hline 352 & 1 & .3 & .3 & 100.0 \\
\hline Total & 386 & 100.0 & 100.0 & \\
\hline
\end{tabular}


Appendix 2. Number of members

\begin{tabular}{|c|c|c|c|c|}
\hline Valid & Frequency & Percent & Valid Percent & Cumulative Percent \\
\hline 0 & 1 & .3 & .3 & .3 \\
\hline 3 & 1 & .3 & .3 & .5 \\
\hline 5 & 95 & 24.6 & 24.6 & 25.1 \\
\hline 6 & 45 & 11.7 & 11.7 & 36.8 \\
\hline 7 & 39 & 10.1 & 10.1 & 46.9 \\
\hline 8 & 59 & 15.3 & 15.3 & 62.2 \\
\hline 9 & 43 & 11.1 & 11.1 & 73.3 \\
\hline 10 & 25 & 6.5 & 6.5 & 79.8 \\
\hline 11 & 15 & 3.9 & 3.9 & 83.7 \\
\hline 12 & 16 & 4.1 & 4.1 & 87.8 \\
\hline 13 & 4 & 1.0 & 1.0 & 88.9 \\
\hline 14 & 12 & 3.1 & 3.1 & 92.0 \\
\hline 15 & 2 & .5 & .5 & 92.5 \\
\hline 16 & 8 & 2.1 & 2.1 & 94.6 \\
\hline 17 & 4 & 1.0 & 1.0 & 95.6 \\
\hline 18 & 8 & 2.1 & 2.1 & 97.7 \\
\hline 19 & 1 & .3 & .3 & 97.9 \\
\hline 20 & 1 & .3 & .3 & 98.2 \\
\hline 26 & 1 & .3 & .3 & 98.4 \\
\hline 29 & 1 & .3 & .3 & 98.7 \\
\hline 35 & 2 & .5 & .5 & 99.2 \\
\hline 45 & 1 & .3 & .3 & 99.5 \\
\hline 48 & 1 & .3 & .3 & 99.7 \\
\hline 50 & 1 & .3 & .3 & 100.0 \\
\hline Total & 386 & 100.0 & 100.0 & \\
\hline
\end{tabular}

